This is an electronic reprint of the original article. This reprint may differ from the original in pagination and typographic detail.

Author(s): Malmelin, Nando; Villi, Mikko

Title: $\quad$ Media work in change : Understanding the role of media professionals in times of digital transformation and convergence

Year: $\quad 2017$

Version:

Please cite the original version:

Malmelin, N., \& Villi, M. (2017). Media work in change : Understanding the role of media professionals in times of digital transformation and convergence. Sociology Compass, 11(7), e12494. https://doi.org/10.1111/soc4.12494

All material supplied via JYX is protected by copyright and other intellectual property rights, and duplication or sale of all or part of any of the repository collections is not permitted, except that material may be duplicated by you for your research use or educational purposes in electronic or print form. You must obtain permission for any other use. Electronic or print copies may not be offered, whether for sale or otherwise to anyone who is not an authorised user. 


\title{
Media work in change: Understanding the role of media professionals in times of digital transformation and convergence
}

\author{
Nando Malmelin \\ Department of Management Studies, Aalto University \\ School of Business
}

\section{Mikko Villi}

Department of Language and Communication Studies, University of Jyväskylä

\begin{abstract}
This article discusses media work and the changes that have swept the media industry from the vantage point of professionals working in media companies and organisations. The concept of media work guides towards new understanding about the media industry and media professions under digital transition. Media work indicates a move towards more diversified job tasks, closer cooperation among different media professions, increased commercial thinking and interaction with audiences.
\end{abstract}

\section{Introduction}

Media work is a relatively novel concept that was coined by Mark Deuze (2007) in his book Media Work and the articles that followed (e.g. Deuze 2009a; 2009b). Deuze's definition of the community of professionals involved in media work is rather broad and holistic, but in this article, we focus especially on work in the media industry. We embrace an understanding of media work that covers particularly media content production, journalistic work, concept development and design, marketing and communication with audiences, as well as online services. 
Media work refers to the processes of planning, producing and marketing media contents, products, services and brands within media organisations. Media work is not limited to journalistic work or content production, but consists also of other activities undertaken by media professionals in order to advance the success of media products and services. This breadth and inclusiveness of the concept reflects the many changes that have been sweeping the media industry in recent years.

In this article, we focus on media work as both an evolving analytical concept and a growing professional field. Drawing on Deuze's theoretical elaborations (e.g. Deuze 2007), media work is approached as a specific concept, not as a general expression referring to work in media and the media industry in general (Hesmondhalgh 2016; Hesmondhalgh \& Baker 2011; for early notions of 'media work' see Gill 2002; Christopherson 2006). We are interested in exploring how the ongoing changes in the media industry impact the work of media professionals. According to Deuze (2007), when examining media work the main dimensions are content, creativity, commerce and connectivity. Accordingly, in this article, we approach media work by studying the integration of professions and skills, media convergence, co-creation and commercialisation.

\section{Integration of media professions and skills}

Media professions have traditionally been differentiated, with various industry sectors having their own job characteristics and requirements. It has long been customary to distinguish between different types of television, radio and newspaper work, for instance, as well as between specific roles in media companies, including journalistic and editorial roles, production and marketing. Recently, however, there has been increasing convergence between media job roles and descriptions, to the extent that it is now possible to talk about media work in a generic 
sense instead of different media industry jobs (Deuze 2007; Deuze 2009a).

These trends have meant that in many job roles, media professionals today need to have a broader range of skills and knowledge (Bakker 2014). Increasingly, the processes of content production and marketing are interwoven and simultaneous, and often the people charged with these tasks are actively involved in other processes as well. Marketing professionals, for instance, are required to have better knowledge of journalistic processes than before, while journalists are expected to show sharper commercial instincts. Given these unified skills and knowledge requirements across different media industry sectors, it is indeed legitimate to talk about a community of media work professionals and a unified set of media work skills. The concept of media work provides a broad and inclusive perspective on working in the media industry.

The concept of media logic has been used to describe the practices and processes that are most distinctive of each media form (Altheide \& Snow 1979; Deuze 2007). Traditionally, television and the print press have had their own, distinct principles, practices and ways of working. Indeed, the concept of media work provides a useful tool with which to integrate different media logics and create a more coherent structure that applies to the media industry as a whole, instead of seeking to define which factors and practices characterise each individual media form.

Integration of the job roles is relatively new trend in the media industry. Corresponding tendencies have been apparent in the marketing and advertising industry for some time. An early example of professional integration in advertising dates from the 1950s when Bill Bernbach brought copywriters and art directors working in advertising agencies together in two-person teams: before they used to work separately in different departments, copywriters in one team and 
graphic designers, together with other visualisation professionals, in another. Bernbach's decision to erase the boundary between these two professional groups and to place greater emphasis on cooperation by reorganising practices in the workplace implied a major change in everyday design work. The team of copywriter and art director became standard practice in the advertising industry throughout the world. (e.g. Nixon 2003, 40-41; Berger 2001.)

Much the same is now happening in media work: people working in the media industry now need a broader range of skills and knowledge about other media jobs and professions. To an ever greater extent, content design and production is a teamwork effort in which a successful outcome requires the bringing together of different viewpoints and ideas. Content producers also need to embrace commercial thinking, marketing skills and brand awareness (see e.g. Cornia, Sehl \& Kleis Nielsen 2016; Thompson 2016). Marketing professionals, for their part, must have a better understanding of media contents so that they can more effectively commercialise them and build attractive media brands (Malmelin \& Moisander 2014).

The changes that are now sweeping the field of media work are largely the outcome of convergence in the media industry. Media convergence can be understood in many different ways, for instance in terms of the integration of communication systems and media forms, the merging of media companies, or the centralisation of their roles and functions (Murdock 2000), or in terms of a cultural shift in which media professionals and the audience contribute jointly to content production and other media work (Jenkins 2006). These shifts and trends can be described as technical, economic or cultural media convergence.

In the everyday practice of media work, convergence has meant, firstly, the ever closer integration of different media sectors as part of the broader media production network. Secondly, roles and functions in the media industry that used to be considered distinct and separate, such as 
creative and commercial roles (Poutanen, Luoma-aho \& Suhanko 2016) or content production and marketing (Tandoc \& Vos 2015), are more and more often incorporated simultaneously in media production. Thirdly, media contents and services are to an increasing extent coproduced (Moisander, Könkkölä \& Laine 2013; Papacharissi 2015), with media professionals joining forces with audiences, advertisers and companies in other areas to produce and distribute media contents. The roles of media companies, consumers and advertisers have thus become increasingly converged, especially in the digital media (Deuze 2009a, 474).

\section{Participatory culture}

The perspective that links media convergence to participatory culture and to co-creation is particularly interesting from the point of view of media work. This highlights a cultural shift that is blurring the boundaries between media production and consumption (Jenkins 2006) as media consumers or audiences become active participants in media production processes. At the same time, audiences are becoming more integrated, forming tighter communities around media products and contents in social media and other online environments (e.g. Malmelin \& Villi 2017; Malmelin \& Villi 2016).

These audience or consumer communities have increasing importance for media companies today as consumers can easily be in contact with one another and share media contents, especially online (Deuze 2009b, 152; Pitta \& Fowler 2005, 284; Kozinets, Valck, Wojnicki \& Wilner 2010). Close ties with media brands lower the threshold for consumers to engage in co-creation, and participation in the brand community may further strengthen the consumer's commitment to a media brand (Hatch \& Schultz 2010, 594; Muniz \& O’Guinn 2001; Schau, Muniz \& Arnould 2009). Media companies may support and nurture consumer communities formed around their brands and reinforce the sense of community. 
Media contents are increasingly produced outside the circle of media professionals. User-generated content (UGC) accounts for a particularly large part of social media contents. This trend in development is also having an impact on design and production processes and in this way changing media work practices. Many media companies are in the process of evolving from content producers into service providers by offering platforms and tools for user interaction (Malmelin \& Villi 2015; Villi 2012). Examples are provided by consumer communities, blogging platforms and tools for sharing news and other content. Indeed, audiences can no longer be regarded simply as groups of passive consumers, but they are actively involved in value creation processes in the media market. In short, old ways of thinking that date from a more industrial media economy are no longer adequate and applicable to the media industry today (Banks \& Humphreys 2008), as the use of media is more than just about the reception and consumption of ready-made media productions (Chan-Olmstead 2006, 31; Livingstone 2008, 394; Merrin 2009, 24).

Participatory culture can also be seen as a threat to journalism and media companies. Audiences are now producing content that is in direct competition with traditional journalism, and in this sense they may be considered to represent a challenge for media professionals (Domingo 2008, 688; Hermida \& Thurman 2008, 347). On the other hand, media companies may also benefit from the contributions of the participatory audience, especially in the areas of content production and distribution (Villi \& Noguera 2017). As a consequence, the job descriptions of increasing numbers of media professionals include interacting with audiences. Furthermore, completely new job descriptions are being born in the media industry, such as that of community manager (Bakker 2014).

Social media are a platform for content production and sharing that in principle is open to all. Social media engender a stronger sense of 
community, but at the same time social media companies use the content created by users and their involvement for their own profit purposes (van Dijck 2013). In other words, social media is a commercial environment, not just an arena for the participation of autonomous users. Also, it is important to note that the major social media services such as Facebook are in direct competition with media companies in the area of online advertising.

This has led to an interesting paradox in the social media. On the one hand, it is pointed out that social media are helping to liberate audiences from the media industry's top-down model, but on the other hand media companies (both traditional and social media companies) are penetrating the domains of content production and social relations and using consumers as a source of free labour (Fuchs 2010; Terranova 2004). The co-creation economy is based on media companies expanding their operation by tying themselves more closely to consumers' media practices and at the same time integrating consumer activities into their own platforms and services and thereby into their own creative processes. Indeed, talk about interaction and coproduction hides from view the fact that media companies benefit commercially from the input of audiences, as audience members rarely receive compensation for the contributions they make to online discussions or for sharing news in social media (Gillmor 2004; van Dijck \& Nieborg 2009, 856; Andrejevic 2009, 47).

\section{Audiences and co-creation}

Media audiences and users have become increasingly autonomous agents with ever greater influence over media contents - their creation, production and distribution. Like many other branches, the media industry is changing so that interaction and cooperation among consumers and companies in the areas of ideation, design and production is emerging as a major practice model. The role of interaction and cooperation with partners and stakeholders is 
emphasised alongside the sale of media products (Prahalad \& Ramaswamy 2004; Ramaswamy \& Gouillart 2010). Media companies should look for new attractive concepts and platforms that make possible the collaboration with consumers.

Co-creation can be defined as an activity in which consumers contribute creatively both to content production and to service innovation and development. Another closely related term is co-production, which refers more narrowly to cooperation in the specific context of content production. As far as media companies are concerned, co-creation requires a preparedness to interact with consumers and consumer communities, which also challenges the clear-cut distinction between company and consumer and between production and consumption. Cocreation involves broad-based interactive processes and service development in collaboration with consumers (Potts et al. 2008, 461; Schau, Muniz \& Arnould 2009, 30-31).

Co-creation is based on the participatory culture where consumers no longer remain in the user and consumer role, but instead want to contribute to creating and developing products and services (Jenkins 2006). Consumers want to have active interaction with companies and to share their views and experiences about products and services with other consumers. Despite this trend many companies, including those in the media industry, continue to follow and promote company-centric business practices.

Consumers are traditionally regarded as relatively passive objects of business marketing and sales efforts. They are categorised on various criteria into different market segments and as members of these segments are offered different products and services. This thinking implies a rather one-way understanding of the interaction between companies and consumers: this is seen as being steered and dictated single-handedly by the company. In so doing, companies fail to take advantage of the opportunity to involve consumers in the processes of 
designing, marketing and developing products and services. Media consumers do not usually have such interaction with media companies that they find meaningful and that would reinforce their commitment to these companies (Domingo et al. 2008; Thurman 2008; Wardle \& Williams 2010).

However, audiences can be extremely valuable to media companies in at least three areas: in content production and the provision of networks, in development and innovation, and as a source of information (Bechmann \& Lomborg 2013). Here, media companies approximate the practices of social media companies as they develop their collaboration with audiences based on co-creative practices. Facebook and other social media companies hardly produce any content themselves, but instead provide a platform for mutual interaction among users. Social media services would not exist without users either in the role of content producers or content distributors. Following the same logic, it can be argued that present-day media companies would not exist without consumer-audiences, but in the future they might not exist without co-creator-audiences.

\section{The commercialisation of media work}

Media professionals work for the most part in commercial businesses such as magazine and publishing houses or radio and television companies. Traditionally, commercial media operations have been based on products and services that are sold to consumers and business companies. The long-standing business model for magazine publishers, for instance, has been to sell magazines to consumers and to sell advertising space in these magazines to companies. Areas of business focus do of course vary by region and by company: in some countries magazines are predominantly sold on a subscription basis and delivered to the customer's door, in others magazines have relied primarily on single copy sales. In addition, the ratio of revenues from 
the sale of magazine advertising space varies depending on the concept of the publication and its target readership (e.g. Picard 2011).

The foundations of doing business in the media industry have changed very rapidly. Media companies following a traditional business model are no longer as profitable as they used to be before. For instance, the decline of advertising in printed magazines and newspapers and the growth in its place of online advertising, the distribution of free online contents and changes in consumers' media behaviour have combined to undermine the industry's traditional business model. In practice, the dual model of combining earnings from both readers and advertisers is outdated in many respects, and media businesses depend increasingly on pulling in money from more diverse revenue sources. Traditional publishing houses are evolving into diversified media corporations with extensive product, service and brand portfolios.

As far as the practices of media work are concerned, this means that commercial considerations regarding media brands and products carry greater weight than before. Competition has intensified in the media market, and commercial success is an increasingly important consideration in content production. In addition, media work increasingly involves the design of new commercial concepts and services as well as the implementation and marketing of new platforms. (Malmelin \& Nivari-Lindström 2017.)

The introduction and integration of commercial thinking as part of media work has provoked much debate among media professionals. Some take the view that commercialism and business management are a threat to journalism, others consider them as key aspects of successful journalistic operations (see also Raviola 2012; Malmelin \& NivariLindström 2017). This contradiction is also reflected at the conceptual level: journalists have conventionally conceived people as audiences, readers, viewers and listeners, whereas marketing staff refer to consumers, customers and target groups. In addition, now with the 
advance of online communication and social media services, people can be increasingly understood as users of media content (Villli \& Matikainen 2016).

Marketing of media content has not traditionally been part of the journalist's job description, but it has now become an area of expertise that is increasingly integral to media work (see e.g. Tandoc \& Vos 2016). Until recently, journalistic work was regarded as a job clearly distinct from the marketing, promotion and sales of media products, but this side now figures ever more prominently in the day-to-day job of content production professionals. Concrete examples include journalism aimed at generating large volumes of audience traffic as well as advertorials - advertisements in the form of editorial content - and content marketing efforts.

Definitions and understandings of marketing have also expanded in the media industry. Traditionally it is thought that marketing and marketing communications should begin when the product is nearing completion and when it is necessary to make sure there is a high level of consumer interest. Nowadays, however, content production and content marketing more and more often go hand in hand. Nor is the marketing of a media product a job for the media company's marketing department alone; content producers such as journalists are increasingly involved in this role as well. Generating interest is critical to the success of media contents and the whole media brand, and content producers have a critical role to play in creating this interest. (Malmelin \& Villi 2016.)

It is always crucial to ensure that there is a large enough and a sufficiently attractive market for media contents that are in planning. The launch of media products should normally be based on a careful analysis of market potential and profitability calculations. The development of new concepts must be grounded in an understanding of the relevant consumer base, and contents and products must be 
weighed and assessed from the point of view of their marketability. Therefore, content producers should also have a stronger understanding of the logic of commercialisation and branding.

One distinctive feature of media brands is that the constantly changing and developing product is also marketing itself. In the media industry the creation of meaningful contents and interesting concepts is in itself a marketing exercise, and investments in developing these contents and concepts can be thought of as investments in customer relations. At the same time, the development of commercial solutions and brand extensions requires that media companies embrace more diverse views of customer needs and interests and of how they are expected to develop in the future (see Chan-Olmstedt 2011; Malmelin \& Moisander 2014).

The marketing of contents is then an important part of media work. One of the principles steering content production is that contents must be both interesting and shareable in online environments (Jenkins, Ford \& Green 2013). Satisfied users will be pleased to inform other potential users about interesting and worthwhile contents, especially in social media, and thus contribute to marketing the service and promoting the brand (Singer 2014; Villi 2012). Sharing contents in social media means two things from the point of view of marketing: firstly, the sharing of good contents creates perceptions and images of a high-quality service, and secondly, it generates debate and reputation that is beneficial to the media brand.

The willingness of users to share their thoughts about contents can also present a risk to the reputation of a brand. Just as users will readily tell others in their networks about things with which they are pleased, so they will readily criticise when they are not satisfied. Negative commentary around a brand may spread very rapidly and lead to adverse and very harmful publicity. 


\section{Conclusions}

The ongoing transformation of the media landscape impacts the work of media professionals. The changes we have described in this article have greatly complicated the media business, and they can also be considered to present a threat to journalism and the journalistic profession. At the same time, it is possible to take an opposite view. That is, the changes that are sweeping the media industry provide an opportunity to reassess media work from novel angles and to innovate and create new ways of working in the media industry.

The role of media professionals is expanding from that of content production towards designing and facilitating different kinds of content products, services and platforms. This does not necessarily mean to say that the importance of traditional journalistic skills is dwindling. As information continues to diversify and become more fragmented, so the quality and credibility of journalism will assume ever greater importance and become a more distinguishing competitive factor (e.g. Meyer 2009). This is the case especially in times when fake news and alternative facts circulating in social media can potentially harm the fabric of civil society. Although it is clear that the professional journalistic community must change in response to the transformations happening in the media industry and develop new practices, we expect the significance of journalism in society to remain lagely intact, despite the efforts to discredit the media.

One of the biggest future challenges facing media companies has to do with the development of their skills base. A major concern for media firms today is how journalists can upgrade their knowledge and skills to meet the requirements of media digitalisation and commercialisation. Of course it could be that the new media environment is so profoundly different from the existing one that media contents in the future will be produced by a different set of people with different sets of skills (Aris 2011, 271-272). 
This line of development also draws attention to the future of the work force in the media industry. Particularly David Hesmondhalgh and Sarah Baker (2011) have shed light on the critical aspects of media work in the context of commercial and industrialized media. An essential question is how the future of journalists and media workers is influenced by such phenomena as precarity. We need further critical elaboration on the future of creative labor and the exploitative dimensions of media work (Hesmondhalgh 2016; Banks \& Hesmondhalgh 2009; Banks 2007). The audience, especially in social media, represents a labour power that produces attention to ads as well as data, which then feeds into the production of ads (Fisher 2015, 65). Importantly, much of the user work or audience labor in social media is associated less with production and more with communication and interaction (Villi \& Matikainen 2016, 111).

Media companies have to develop new business models and business strategies, which often means that commercialism and innovation will have an increasingly prominent role in future media work. Media companies will also need new kinds of skills in multichannel publishing and in the use of digital platforms and technologies. These skills may be described as convergence skills (Bartosova 2011, 196). They include knowledge and skills needed in project management and interaction.

One major growth area for media work is the creation of online services and the development and nurturing of online communities. The roles of media professionals in online media work are different from those in traditional journalistic work. Indeed, the roles of managers in media companies increasingly have to do with managing networks of collaboration and developing systems and processes that support creativity and interaction (Bilton 2007, 58-59; Deuze \& Steward 2011, 8; see also Puccio, Murdock \& Mance 2007). Thus, the context of media work must be viewed not as a value chain, but more broadly as value networks in which companies, consumers, partners and subcontractors 
work closely with one another (Küng 2008, 19-20; Bilton 2011, 37; Jenkins, Ford \& Green 2013). Media work and the management of media work are increasingly about co-creation and the coordination and management of partnerships.

\section{References}

Altheide, David L. and Robert P. Snow 1979. Media Logic. Beverly Hills \& London: Sage

Andrejevic, Mark 2009. "Critical Media Studies 2.0: An Interactive Upgrade." Interactions: Studies in Communication \& Culture 1(1): 35-51.

Aris, Annet 2011. "Managing Media Companies Through the Digital Transition." Pp. 265-278 in Managing Media Work, edited by Mark Deuze. Los Angeles: Sage.

Bakker, Piet 2014. "Mr. Gates returns: Curation, community management and other new roles for journalists." Journalism Studies,15(5): 596-606.

Banks, Mark 2007. The politics of cultural work. Basingstoke: Palgrave.

Banks, Mark and David Hesmondhalgh 2009. "Looking for work in creative industries policy". International Journal of Cultural Policy 15(4) 415-430.

Banks, John and Sal Humphreys 2008. "The Labour of User Co-Creators: Emergent Social Network Markets?" Convergence: The International Journal of Research into New Media Technologies 14(4): 401-418.

Bartosova, Daniela 2011. "The future of the media professions: Current issues in media management practice." International Journal on Media Management 13(3): 195-203. 
Bechmann, Anja \& Stine Lomborg 2013. "Mapping Actor Roles in Social Media: Different Perspectives on Value Creation in Theories of User Participation." New Media \& Society 15(5): 765-781.

Berger, Warren 2001. Advertising today. London: Phaidon.

Bilton, Chris 2007. Management and Creativity. From Creative Industries to Creative Management. Malden: Blackwell.

Bilton, Chris 2011. "The Management of the Creative Industries. From Content to Context" Pp. 31-42 in Managing Media Work, edited by Mark Deuze. Los Angeles: Sage.

Chan-Olmsted, Sylvia M. 2006. Competitive Strategy for Media Firms: Strategic and Brand Management in Changing Media Markets. Mahwah, New Jersey: Lawrence Erlbaum Associates.

Chan-Olmsted, Sylvia M. (2011). "Media branding in a changing world: Challenges and opportunities 2.0." International Journal on Media Management 13(1): 3-19.

Christopherson, Susan 2006. "Behind the scenes: How transnational firms are constructing a new international division of labor in media work." Geoforum 37(5): 739-751.

Cornia, Alessio, Annika Sehl and Rasmus Kleis Nielsen 2016. Private Sector Media and Digital News. Oxford, UK: Reuters Insititute for the Study of Journalism.

Deuze, Mark 2007. Media Work. Cambridge: Polity Press.

Deuze, Mark 2009a. "Media industries, work and life." European journal of communication 24(4): 467-480. 
Deuze, Mark 2009b. "Convergence Culture and Media Work." Pp. 144156 in Media Industries: History, Theory, and Method, edited by Jennifer Holt and Alisa Perren. Chichester, UK: Wiley-Blackwell.

Deuze, Mark and Brian Steward 2011. "Managing Media Work." Pp. 110 in Managing Media Work, edited by Mark Deuze. Los Angeles: Sage.

Domingo, David 2008. "Interactivity in the Daily Routines of Online Newsrooms: Dealing with an Uncomfortable Myth." Journal of Computer-Mediated Communication 13(3): 680-704.

Domingo, David, Thorsten Quandt, Ari Heinonen, Steve Paulussen, Jane B. Singer, and Marina Vujnovic 2008. "Participatory journalism practices in the media and beyond: An international comparative study of initiatives in online newspapers." Journalism Practice 2(3): 326-342.

Fisher, Eran 2015. "'You Media': Audiencing as Marketing in Social Media." Media, Culture \& Society 37(1): 50-67.

Fuchs, Christian 2010. "Labor in Informational Capitalism and on the Internet." The Information Society 26(3): 179-196.

Gill, Rosalind 2002. "Cool, creative and egalitarian? Exploring gender in project-based new media work in Euro." Information, communication \& society 5(1): 70-89.

Gillmor, Dan 2004. We the Media: Grassroots Journalism by the People, for the People. Sebastopol, CA: O’Reilly Media.

Hatch, Mary Jo and Majken Schultz 2010. "Toward a Theory of Brand Co-Creation with Implications for Brand Governance." Journal of Brand Management 17(8): 590-604. 
Hermida, Alfred and Neil Thurman 2008. "A Clash of Cultures: The Integration of User-Generated Content within Professional Journalistic Frameworks at British Newspaper Websites." Journalism Practice 2(3): 343-356.

Hesmondhalgh, David 2016. "Exploitation and media labor." Pp. 30-39 in The Routledge companion to labor and media, edited by Richard Maxwell. New York \& London: Routledge

Jenkins, Henry 2006. Convergence Culture. New York: NYU Press.

Jenkins, Henry, Sam Ford and Joshua Green 2013. Spreadable Media: Creating Value and Meaning in a Networked Culture. New York \& London: New York University Press.

Kozinets, Robert V., Kristine De Valck, Andrea C. Wojnicki and Sarah J. S. Wilner 2010. "Networked Narratives: Understanding Word-of-Mouth Marketing in Online Communities." Journal of Marketing 74(2): 71-89.

Küng, Lucy 2008. Strategic Management in the Media: Theory to Practice. London: Sage.

Malmelin, Nando and Johanna Moisander 2014. "Brands and branding in media management-Toward a research agenda." International Journal on Media Management 16(1): 9-25.

Malmelin, Nando and Lotta Nivari-Lindström 2017. "Rethinking creativity in journalism: Implicit theories of creativity in the Finnish magazine industry." Journalism 18(3): 334-349.

Malmelin, Nando and Mikko Villi 2017. "Co-creation of what? Modes of audience community collaboration in media work." Convergence: The International Journal of Research into New Media Technologies 23(2): 182-196. 
Malmelin, Nando and Mikko Villi 2016. "Audience Community as a Strategic Resource in Media Work: Emerging practices." Journalism Practice 10(5): 589-607.

Merrin, William 2009. "Media Studies 2.0: upgrading and open-sourcing the discipline." Interactions: Studies in Communication and Culture 1(1): 17-34.

Meyer, Philip 2009. The Vanishing Newspaper. Saving Journalism in the Information Age. Columbia: University of Missouri Press.

Moisander, Johanna, Saara Könkkölä and Pikka-Maaria Laine 2013. "Consumer Workers as Immaterial Labour in the Converging Media Markets: Three Value-Creation Practices." International Journal of Consumer Studies 37(2): 222-227.

Muniz, Jr., Albert M. and Thomas C. O’Guinn 2001. "Brand Community." Journal of Consumer Research 27(4): 412-432.

Murdock, Graham 2000. "Digital Futures: European Television in the Age of Convergence." Pp. 35-58 in Television Across Europe: A Comparative Introduction, edited by Jan Wieten, Graham Murdock and Peter Dahlgren. London: Sage.

Nixon, Sean 2003. Advertising cultures. Gender, commerce, creativity. London: Sage.

Papacharissi, Zizi 2015. "Toward New Journalism(s): Affective News, Hybridity, and Liminal Spaces." Journalism Studies 16(1): 27-40.

Picard, Robert G. 2011. The economics and financing of media companies. New York: Fordham University Press. 
Pitta, Dennis A. and Danielle Fowler 2005. "Online Consumer Communities and Their Value to New Product Developers." Journal of Product \& Brand Management 14(5): 283-291.

Potts, Jason, John Hartley, John Banks, Jean Burgess, Rachel Cobcroft, Stuart Cunningham and Lucy Montgomery 2008. "Consumer CoCreation and Situated Creativity." Industry \& Innovation 15(5): 459474.

Poutanen, Petro, Vilma Luoma-aho and Elina Suhanko 2016. "Ethical Challenges of Hybrid Editors." International Journal on Media Management 18(2): 99-116.

Prahalad, C. K. \& Venkat Ramaswamy 2004. "Co-creation experiences: The next practice in value creation." Journal of Interactive Marketing 18(3): 5-14.

Puccio Gerard J., Mary C. Murdock and Marie Mance 2007. Creative leadership: Skills that drive the change. Thousand Oaks: Sage.

Ramaswamy, Venkat and Francis Gouillart 2010. The Power of CoCreation. Build It With Them to Boost Growth, Productivity, and Profits. New York: Free Press.

Raviola, Elena 2012. "Exploring organizational framings: Journalism and business management in newspaper organizations." Information, Communication \& Society 15(6): 932-958.

Schau, Hope Jensen, Albert M. Muniz, Jr. and Eric J. Arnould 2009. How Brand Community Practices Create Value. Journal of Marketing 73(5): 30-51.

Singer, Jane B. 2014. "User-generated visibility: Secondary gatekeeping in a shared media space." New Media \& Society 16(1): 55-73. 
Tandoc, Edson C. and Tim P. Vos. 2016. "The Journalist Is Marketing the News: Social Media in the Gatekeeping Process." Journalism Practice 10 (8): 950-66.

Terranova, Tizian 2004. Network culture. Politics for the information age. London: Pluto Press.

Thurman, Neil 2008. "Forums for Citizen Journalists? Adoption of User Generated Content Initiatives by Online News Media." New Media \& Society 10(1): 139-157.

Thompson, Mark 2016." The Challenging New Economics of Journalism.” Pp. 107-108 in Reuters Institute Digital News Report 2016, edited by Nic Newman, Richard Fletcher, David A.L. Levy and Rasmus Kleis Nielsen. Oxford, UK: Reuters Insititute for the Study of Journalism.

Van Dijck, José 2013. The Culture of Connectivity: A Critical History of Social Media. Oxford: Oxford University Press.

Van Dijck, José and David Nieborg 2009. "Wikinomics and its discontents: a critical analysis of Web 2.0 business manifestos." New Media \& Society 11(5): 855-874.

Villi, Mikko 2012. "Social Curation in Audience Communities: UDC (User-distributed Content) in the Networked Media Ecosystem." Participations: The International Journal of Audience and Reception Studies 9(2): 614-632.

Villi, Mikko and Janne Matikainen 2016. "Participation in Social Media: Studying Explicit and Implicit Forms of Participation in Communicative Social Networks." Media and Communication 4(4): 109-17. 
Villi, Mikko and José Manuel Noguera Vivo 2017. "Sharing Media Content in Social Media: The Challenges and Opportunities of UDC (User-Distributed Content)." Journal of Applied Journalism \& Media Studies 6(2), forthcoming.

Wardle, Claire and Andrew Williams 2010. "Beyond user-generated content: a production study examining the ways in which UGC is used at the BBC." Media, Culture \& Society 32(5): 781-799. 